\title{
Virus-Induced Diabetes in Mice: A Quantitative Evaluation of Islet Cell Population by Immunofluorescence Technique
}

\author{
Y. Stefan ${ }^{1}$, F. Malaisse-Lagae ${ }^{1}$, J. W. Yoon ${ }^{2}$, A. L. Notkins ${ }^{2}$, and L. Orci ${ }^{1}$ \\ 1 Institute of Histology and Embryology, University of Geneva Medical School, Geneva, Switzerland, and \\ ${ }^{2}$ Laboratory of Oral Medicine, National Institute of Dental Research, National Institutes of Health, Bethesda, Maryland, USA
}

\begin{abstract}
Summary. The endocrine cell populations of pancreatic islets in encephalomyocarditis (EMC)-virus infected mice were assessed quantitatively by immunofluorescence using specific antisera against 4 islet hormones. A marked reduction of the volume of insulin-containing (B-) cells (up to one tenth of control values) was observed at all stages studied in the hyperglycaemic mice. This was accompanied by the inversion of the normal ratio between $\mathrm{B}$ - and non $\mathrm{B}$ cells. The volume of the latter cell types was also modified at different time points after infection: glucagon-cells were augmented 14 days after infection; PP-cells were decreased 2-3 days and 21 days after infection; somatostatin-cells decreased to onefourth of control values in hyperglycaemic animals 21 days after infection. The latter results suggest that non B-cells are also involved in islet reaction to virus infection.
\end{abstract}

Key words: Diabetes, EMC-virus, islet cells, immunofluorescence, morphometry.

Viral infection in experimental animals has proved a valuable model system of diabetes. In some strains of mice, infection with the $M$ variant of the encephalomyocarditis (EMC) virus induces a diabetes-like syndrome characterized by initial hypoglycaemia, soon followed by hyperglycaemia, hypoinsulinaemia, glycosuria, polydipsia and polyphagia [1-7]. In DBA/ 2 male mice, 60 to $80 \%$ of the infected animals develop hyperglycaemia. The diabetic state, however, is not permanent, since only 10 to $15 \%$ of the animals remain hyperglycaemic after 6 months [1].

In the pancreas, the viral infection induces a partial destruction of the islets of Langerhans, while the exocrine tissue is barely affected. Virus has been detected by immunofluorescence in the B-cells [8]. There is usually a good correlation between the severity of hyperglycaemia and the degree of B-cell alteration [8].

Basic information on the reactivity of pancreatic endocrine cells can be obtained by morphometric analysis of the various cell types identified by the immunofluorescence technique. In previous studies from this and other laboratories, investigations of this type have been done in rats with streptozotocin [9-11] or alloxan diabetes $[12,13]$ and in hyper- or hypoinsulinaemic diabetic C57BL mice from Bar Harbor [14]. It was observed that not only the insulin-producing B-cells but also the other endocrine cell types of the islet showed marked quantitative variations.

To investigate the reactivity of different endocrine cells of the islets in virus-induced diabetes, male mice of the SWR/J strain were inoculated with the M variant of the EMC virus and sacrificed at different time intervals following infection. In the present study, we have: a) identified insulin-, glucagon-, pancreatic polypeptide (PP)-, and somatostatin-containing cells by immunofluorescence [15] using specific antibodies against the respective hormones; $b$ ) assessed quantitatively the different islet cell types by morphometry; and c) compared the results to those obtained previously in our laboratory in streptozotocin-diabetic rats [9-11] and genetically diabetic mice $[14,16]$.

\section{Material and Methods}

\section{Animals and Experimental Procedure}

Male SWR/J mice were infected at the age of 5-6 weeks with the $\mathrm{M}$-variant of EMC virus (5 X $10^{3} \mathrm{PFU} / \mathrm{ml} /$ mouse) inoculated intraperitoneally [1]. 
In the first experiment ("batch" experiment, I), 50 mice were infected and groups of 10 randomly chosen animals were sacrificed at $2,3,7,14$ and 21 days after infection. Non-fasting blood glucose levels were measured at the time of sacrifice [1].

In non-infected animals mean blood glucose level was $150 \mathrm{mg} /$ dl (range 102-205). Ten out of the 20 mice sacrificed 2 and 3 days after infection had a blood glucose level lower than $102 \mathrm{mg} / \mathrm{dl}$, whereas $83 \%$ of the mice killed after 7,14 and 21 days had blood glucose levels above $205 \mathrm{mg} / \mathrm{dl}$.

Analysis of the pancreas was performed in the 5 most hyperglycaemic animals of each group of mice sacrificed 7, 14 and 21 days after infection. The 5 most hypoglycaemic mice among the 20 animals sacrificed 2 or 3 days after infection were also studied, since the hypoglycaemia observed at that stage has been assumed to result from leakage of insulin from damaged B-cells [6] and, hence, to represent the first manifestation of ongoing diabetes.

In the second experiment (II), 60 mice were infected and blood glucose levels were measured in each animal 1, 2, 3, 5, 7 and 8 weeks after infection. All animals were then sacrificed and divided in 3 groups: (a) 2 persistently hyperglycaemic animals; (b) normoglycaemic animals which had a transient hyperglycaemia (5 of which were analyzed); (c) persistently normoglycaemic animals (the pancreas of those latter mice was not analyzed). Also studied were 3 control groups of 5 animals each, aged 5-6 weeks, 8-9 weeks and 13-14 weeks, respectively.

\section{Histoimmunological Techniques}

The tail and body of the pancreas were removed in one block, fixed in Bouin solution for 18-20 h, then rinsed in tap water overnight. The volume of the fixed tissue was measured by immersion according to Archimedes principle. After dehydration through increasing concentrations of ethanol, the tissue was embedded in paraffin. Sections $(5 \mu \mathrm{m})$ were cut and series of 5 serial sections prepared; in each series, one section was stained with haemalumeosin and the remaining sections treated by the immunofluorescence technique of Coons et al [15], with one of the following sera:

- Guinea-pig anti-pig-insulin serum (a gift of Dr. P. H. Wright, Indianapolis, U.S.A.) at a 1:100 dilution.

- Rabbit anti-pig-glucagon serum (15K; a gift of Dr. R. H. Unger, Dallas, U.S.A.) at a 1:20 dilution.

- Rabbit anti-synthetic-somatostatin serum (a gift from Dr. M. P. Dubois, Nouzilly, France) at a 1:50 dilution.

- Rabbit anti-ox-pancreatic polypeptide serum (a gift of Dr. R. E. Chance, Indianapolis, U.S.A.) at a 1:40 dilution.

The rehydrated sections were incubated first with the antisera for two hours, then with anti-rabbit or antiguinea pig globulin antisera labelled with fluorescein isothiocyanate (Pasteur Institute, Paris, France) for 1 hour, and finally counterstained with Evans blue $(0.01 \%)$. All reagents were diluted with phosphate buffered saline, and the reactions were carried out at room temperature. Inhibition tests were performed for each antiserum by absorption with its homologous antigen $(80 \mu \mathrm{g}$ of pig insulin, $100 \mu \mathrm{g}$ of pig glucagon, $100 \mu \mathrm{g}$ of synthetic cyclic somatostatin and $100 \mu \mathrm{g}$ of ox pancreatic polypeptide per $\mathrm{ml}$ of undiluted antiserum).

The incubated sections were examined on a Zeiss Ultraphot II photomicroscope equipped for fluorescence (excitation filters: BG 12 and KP 500; barrier filter $\mathrm{Nr} 53$ ).

\section{Morphometric Analysis}

3.1. Volume of Endocrine Pancreas. The measurements were performed on sections stained with haemalum-eosin. The volume density $(\mathrm{Vv})$ of endocrine tissue in the pancreas was obtained by the point-counting method of Weibel [17] according to the following formula:
$\mathrm{V} v$ endocrine $=\frac{\mathrm{P} \text { islets }}{\mathrm{P} \text { pancreas }}$

$\mathrm{P}$ islets $=$ points of the lattice over islets

$\mathrm{P}$ pancreas $=$ points of the lattice over the total pancreas, including ducts, vessels, nerves, lymph nodes, connective and adipose tissue. Volume of endocrine tissue was obtained by multiplying the volume density of endocrine tissue by the volume of the pancreatic sample.

3.2. Volume Density and Total Volume of Endocrine Cells. The first 20 islets encountered in examining each section incubated with one of the antisera were photographed. As far as possible, the same 20 islets in each of the 3 consecutive sections stained with different antisera were photographed. Whenever the number of islets in one section was less than 20 , one or several series of additional sections were used, each series $100 \mu \mathrm{m}$ from one another. For the determination of the volume density (Vv) of each cell type within the islets, the original formula of Weibel (see above) was modified [18] according to Cahn and Nutting [19] in order to correct the overestimation due to the superposition within the thickness of the section of fluorescent and non-fluorescent structures.

The formula was as follows:

$\mathrm{Vv}=\frac{\mathrm{P} \text { cells }}{\mathbf{P} \text { islet }}-\frac{\mathrm{T}}{2} \times \frac{\text { Icells }}{2 \mathrm{P} \text { islet } \times \mathrm{d}}$

$\mathrm{P}$ cells $=$ points of the lattice over fluorescent cells

$\mathrm{P}$ islet $=$ points of the lattice over the islet

$\mathrm{T}=$ thickness of the section

I cells $=$ Intersections of each horizontal and vertical line of the lattice with isolated or clustered fluorescent cells.

$\mathrm{d}=$ Distance between horizontal and vertical lines of the lattice.

The total volume occupied by each cell type in the pancreas was obtained by multiplying its volume density in the islet by the volume of endocrine tissue.

The values obtaines for each group of animals were compared by the " $\mathrm{t}$ " test of Student-Fisher.

\section{Results}

\section{General Morphology}

The morphological changes induced by the $\mathrm{M}$-variant of EMC virus in the islets are illustrated in Figure 1. At 2-3 days after infection, necrosis appeared in isolated cells scattered throughout the islets and in groups of cells located at the periphery of the islets of Langerhans, which remained of normal size (Fig. 1b). At this and following stages of infection, normal looking islets were also observed. At 7 and 14 days after infection, most islets were considerably decreased in size, and characterized by leucocytic infiltration (Fig. 1c). At 21 days, concomitant with islet atrophy, (Fig. 1d) the number of islets present in a section was strikingly reduced. At all stages acinar cells were rarely damaged, but during the first days of infection the interstitial spaces of the exocrine pancreas and the peri-insular regions frequently 


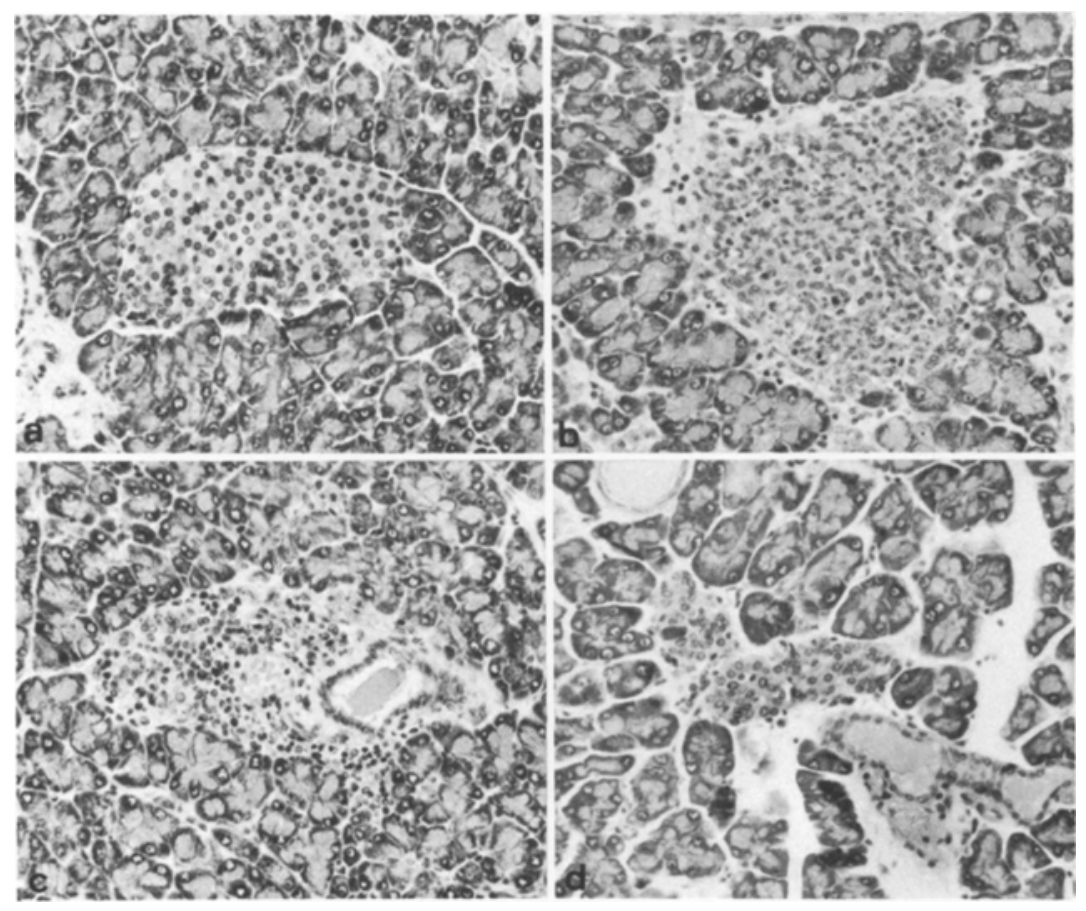

Fig. 1. Islets stained with haemalum-eosin: $\mathbf{a}$ of a control mouse. $\mathbf{b}$ of an hypoglycaemic mouse 3 days after infection: partial cell necrosis. $\mathbf{c}$ of an hyperglycaemic mouse 7 days after infection: numerous leucocytes are found within the islet. $d$ of an hyperglycaemic mouse 21 days after infection: the small islet is devoid of inflammatory cells. $\times 150$ appeared oedematous and infiltrated by leucocytes. There was a good correlation between the extent of islet damage and blood glucose concentration, since the majority of islets were damaged in the severely hyperglycaemic mice, but only a few in the nonhyperglycaemic infected animals. At 8 weeks after infection, most of the islets of mice with a transient hyperglycaemia had a normal size and structure, whereas the islets of the 2 mice with persistent hyperglycaemia were similar to those observed after 21 days of infection.

Quantitative evaluation of the morphological changes (Fig. 2) revealed that endocrine tissue volume was not reduced 2-3 days after infection, but that is was significantly decreased at 7 and 21 days after infection. The absence of a significant decrease in endocrine tissue volume at 14 days post-infection may be ascribed in part to particularly large individual variations at this stage and also to the fact that infected mice have been compared to controls which were not strictly age-matched. By contrast, the volume of exocrine tissue was found constant over the entire experimental period.

\section{Observations by Immunofluorescence}

2.1. At the Level of the Islet. Qualitative images of immunofluorescent cells are illustrated in Figure 3. Quantitative data relative to the islet (volume density) are given in Tables 1 and 2.

In control mice, insulin-containing B-cells

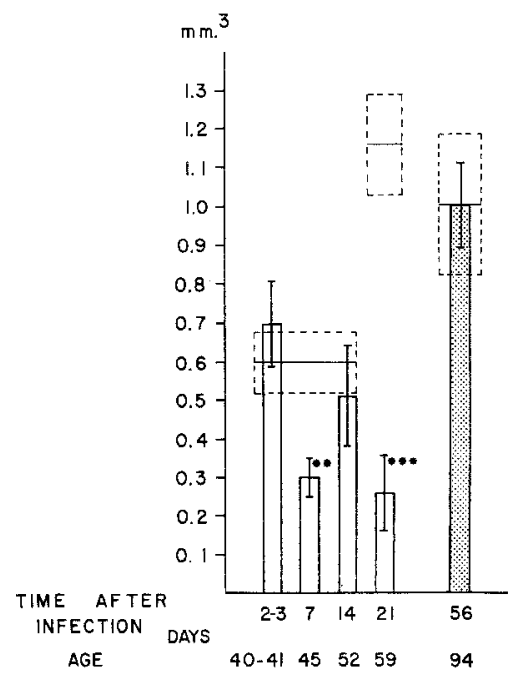

Fig. 2. Mean values $(\mathrm{n}=5) \pm$ SEM of the volume of endocrine tissue in the pancreas of virus-infected mice; the blocks delineated by interrupted lines give values of control mice aged 38,59 and 94 days, respectively; the stippled bar refers to mice which had recovered from hyperglycaemia. The asterisks indicate significance of the observed differences $(* * \mathrm{P}<0.01 ; \mathrm{P} * * *<0.001)$

showed intense fluorescence and occupied nearly the entire islet section. The non B-cells showing a positive reaction with anti-glucagon, anti-PP and antisomatostatin serum respectively were less numerous and situated mostly at the periphery of the islet (Fig. 3, left panel).

Two or 3 days after infection, in those mice which 

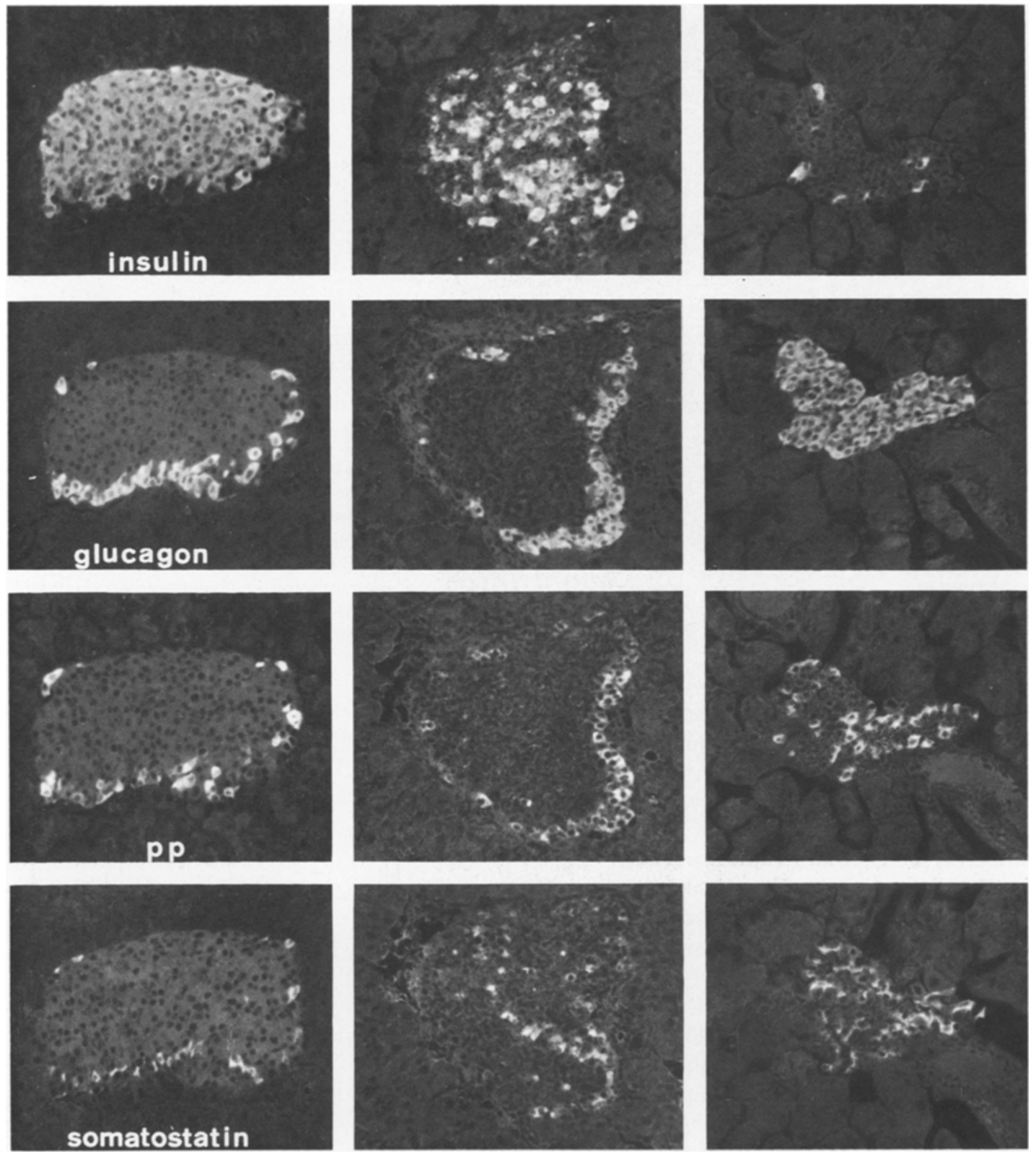

Fig. 3. Immunofluorescent reactions in serial sections of pancreas of: 1) a control mouse (left panel): note the peripheral localization of the non-B-cells. 2) an hypoglycaemic mouse 3 days after infection (middle panel): glucagon and PP-immunofluorescent cells are still located at islets periphery; several somatostatin immunofluorescent cells can be seen in the centre of the islet 3 ) an hyperglycemic mouse 21 days after infection (right panel): note the reduction of islet size, scarcity of insulin-immunofluorescent cells and abundance of glucagon-immunofluorescent cells; PP- and somatostatin-immunofluorescent-cells are scattered throughout the islet. $\times 165$

were hypoglycaemic, small clusters of insulin-containing cells subsisted in the centre of the islet. Glucagon and PP-immonufluorescent cells were located, as in controls, at the islet periphery, while weakly fluorescent somatostatin containing cells were scattered throughout the islet (Fig. 3, middle panel). Compared to control values, the volume density of all 4 islet cell types was decreased (Table 1). At this stage, several cells appeared in the islet which did not react with any of the antisera tested (see below).

In the hyperglycaemic mice examined at later times after infection, insulin-immunofluorescent cells were scarce and isolated from one another. The bulk of the islet was constituted by glucagon-containing cells grouped in clusters, surrounded by somatostatin- and PP-containing cells (Fig. 3, right panel). As at earlier stages, a significant proportion of cells in 
Table 1. Mean values \pm SEM of the non-fasting blood glucose levels at time of sacrifice and the volume density (Vv/islet) of the different endocrine cell types. Significance of differences with control mice: $\mathrm{a}=\mathrm{P}<0.001 ; \mathrm{b}=\mathrm{P}<0.025 ; \mathrm{c}=\mathrm{P}<0.05$ (control $=38$ days for values obtained up to 14 days after infection; control $=59$ days for values at 21 days after infection

\begin{tabular}{llllllll}
\hline $\begin{array}{l}\text { Age } \\
\text { (days) }\end{array}$ & $\mathbf{n}$ & $\begin{array}{l}\text { Days } \\
\text { after } \\
\text { infection }\end{array}$ & $\begin{array}{l}\text { Blood glucose } \\
(\mathrm{mg} / \mathrm{dl})\end{array}$ & $\begin{array}{l}\text { Insulin } \\
\text { cells }\end{array}$ & $\begin{array}{l}\text { Golume density (Vv)/Islet } \\
\text { cells }\end{array}$ & $\begin{array}{l}\text { PP } \\
\text { cells }\end{array}$ & $\begin{array}{l}\text { Somatostatin } \\
\text { cells }\end{array}$ \\
\hline 38 & 5 & - & $151 \pm 14$ & $0.765 \pm 0.013$ & $0.079 \pm 0.011$ & $0.040 \pm 0.003$ & $0.039 \pm 0.006$ \\
$40-41$ & 5 & $2-3$ & $82 \pm 2$ & $0.376 \pm 0.035^{\mathrm{a}}$ & $0.052 \pm 0.035$ & $0.018 \pm 0.003^{\mathrm{a}}$ & $0.024 \pm 0.003$ \\
45 & 5 & 7 & $527 \pm 8$ & $0.081 \pm 0.010^{\mathrm{a}}$ & $0.234 \pm 0.027^{\mathrm{a}}$ & $0.091 \pm 0.006^{\mathrm{a}}$ & $0.080 \pm 0.005^{\mathrm{a}}$ \\
52 & 5 & 14 & $490 \pm 17$ & $0.235 \pm 0.039^{\mathrm{a}}$ & $0.211 \pm 0.021^{\mathrm{a}}$ & $0.079 \pm 0.011^{\mathrm{a}}$ & $0.064 \pm 0.009^{\mathrm{c}}$ \\
59 & 5 & 21 & $553 \pm 58$ & $0.224 \pm 0.059^{\mathrm{a}}$ & $0.244 \pm 0.031^{\mathrm{a}}$ & $0.092 \pm 0.016^{\mathrm{b}}$ & $0.090 \pm 0.013$ \\
59 & 5 & - & $160 \pm 3$ & $0.768 \pm 0.009$ & $0.068 \pm 0.004$ & $0.045 \pm 0.004$ & $0.097 \pm 0.005$ \\
\hline
\end{tabular}

the islet were not fluorescent to any of the antibodies tested at 7,14 and 21 days. These nonfluorescent cells could represent leucocytes, necrotic cells, and/ or endocrine cells thoroughly depleted of their secretory product. In all infected mice, some islets showed a pattern of immunofluorescent staining similar to that of control islets.

Day 7 of infection appeared to be the peak time of damage to the insulin-containing cells and at this stage the perturbation of the normal ratio of B-cells over non B-cells was maximal. At days 14 and 21, the volume density of insulin-containing cells was higher than at 7 days, and the altered ratio of B-cells to non B-cells was moving towards normal (Table 1). This ratio was further improved in the 2 persistently hyperglycaemic animals 56 days after infection (Table 2).

In the islets of the animals which were no longer hyperglycaemic when sacrificed, the different immunofluorescent cell types presented a normal topographical distribution, as well as normal respective volume densities (Table 2).

\subsection{Extrapolation of Islet Data to the Whole Pan-} creas. Values of total volume of each immunofluorescent cell type are shown in Fig. 4. This volume was reduced for all immunofluorescent cell populations 2-3 days after infection, at a time when the total volume of islets was not yet diminished.

A further and considerable decrease of insulincontaining cells was observed at day 7 of infection. 14 and 21 days after infection, the total volume of insulin cells was slightly higher than at 7 days, but remained very low when compared to control values. In the animals which had recovered a normal blood glucose concentration and were sacrificed 56 days after infection, the volume of insulin-containing cells was within the normal range. By contrast, in the two persistently hyperglycaemic animals surviving 8

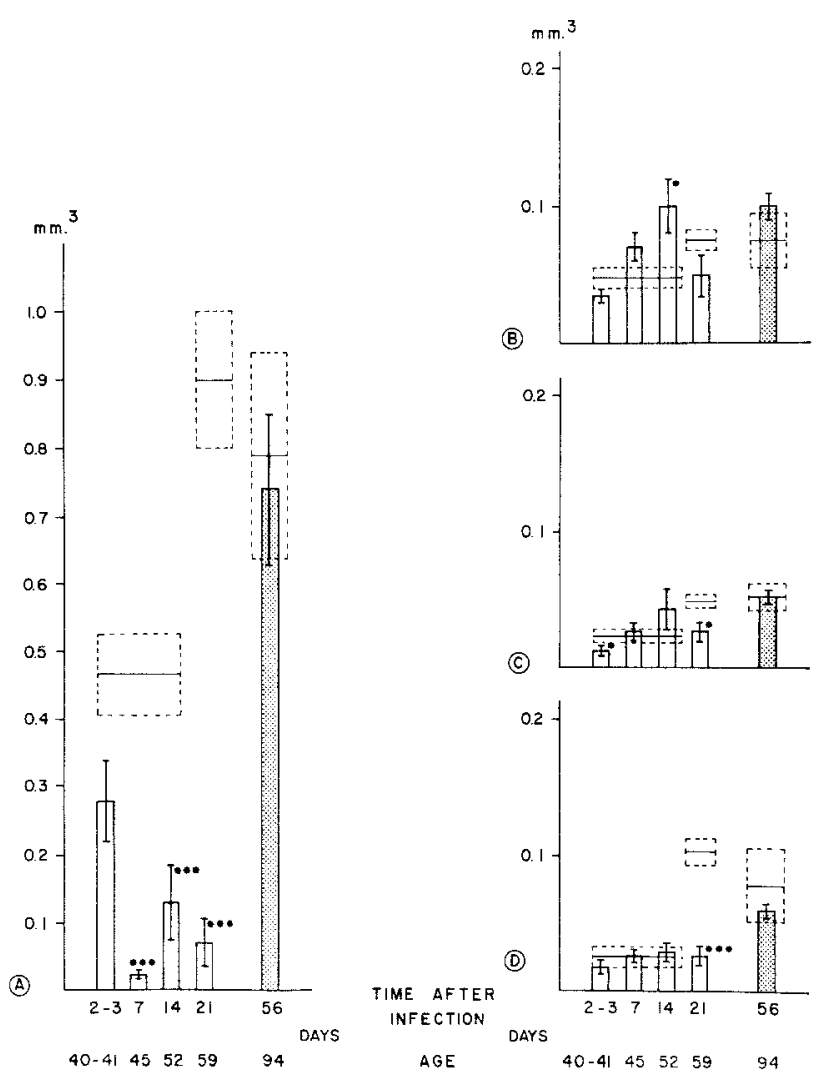

Fig. 4. Mean values $(n=5) \pm$ SEM for the volume of insulin- $(A)$, glucagon(B), PP- (C), and somatostatin-containing cells (D) in the pancreas of virus-infected mice; the blocks delineated by interruptions give control values; the stippled bars refer to mice which had recovered from hyperglycaemia. The asterisks indicate: ${ }^{*} \mathrm{P}<0.05$; $* * \mathrm{P}<0.01 ; * * * \mathrm{P}<0.001$

weeks after infection, the total volume of insulin-cells was far below that of controls (Table 2). 7 and 14 days after infection, the total volume of non-B-cells fluctuated around control values, the only exception being a barely significant increase of glucagon cells at 14 days (Fig. 4).

21 days after infection, however, the volume of 
glucagon, PP and somatostatin cells was lower than control values, the difference being highly significant in the case of somatostatin containing cells (Fig. 4).

56 days after infection, values obtained for nonB-cells in transiently hyperglycaemic mice were within the normal range, but were well below normal range in the 2 persistently hyperglycaemic animals (Table 2).

\section{Discussion}

As reported for other hypoinsulinaemic diabetic syndromes in rodents $(\mathrm{ob} / \mathrm{ob}$ or $\mathrm{db} / \mathrm{db} \mathrm{C} 57 \mathrm{BL} / \mathrm{KsJ}$ mice, streptozotocin-injected rats; $[9-11,14,16])$, the architecture of the islets of Langerhans was profoundly altered in EMC-virus infected $\mathrm{SWR} / \mathrm{J}$ hyperglycaemic mice: severe reduction of the number of B-cells and invasion of the islet by non Bcells, which are normally situated in small amounts at the periphery of the islet. This induced a reversal of the normal ratio between B-cells and non B-cells, with the remaining $\mathrm{B}$-cells establishing contacts mainly with non B-cells.

Our results support the concept that one main feature of EMC-virus induced diabetes is B-cell necrosis $[5,8,20,21]$ : the total volume of insulinfluorescent cells was greatly decreased after a few days post-infection, it remained low in hyperglycaemic animals but returned to normal in animals that recovered from hyperglycaemia. Insulin content of the pancreas has been shown to follow a similar pattern, as well as B-cell responsiveness to secretory stimuli [22].

The main interest of our quantitative analysis is the fact that the total volume of each endocrine cell population could be evaluated. This allowed us to pinpoint an hitherto unsuspected aspect of virusinduced islet damage, namely that non B-cells too may be involved in islet reaction to viral infection; in support of this are the following arguments:

1. A decrease of the volume of the three cell types is first observed 2-3 days after infection. This time point corresponds to that at which the highest concentration of virus is detected by immunofluorescence in the islet [8]. This suggests that a number of non B-cells are damaged during the acute phase of virus infection as indicated by the fact that the biosynthetic activity of glucagon-containing cells was found to be reduced in islets removed from 3 daysinfected mice [23].

2.7 and 14 days after infection, the total volume of glucagon-cells is moderately increased. This may be related to the observation of Zaheer et al [22] who noticed an increase in glucagon release in response to 
theophylline 7 days after infection when compared with controls.

3. 21 days after infection, the volumes of glucagon-, PP-, and somatostatin-cells are lower than those of age-matched controls. This is also the case for the 2 persistently hyperglycaemic animals sacrificed 8 weeks after infection.

To explain the alteration of non B-cells, one may think of a) an indirect adverse effect of necrotic Bcells on surrounding non B-cells or b) a direct effect of EMC virus not on B-cells only but also on non Bcells. In favour of the latter hypothesis is the observation, 2-3 days after infection, of frequent necrotic foci at the periphery of the islets where somatostatin, glucagon, and PP-cells are likely to be located. Using two differently labelled antibodies (antibody to EMC-virus labelled with fluorescein and antibodies to glucagon, somatostatin or PP labelled with rhodamin), we are currently investigating whether EMCvirus multiplication may occur in non B-cells.

Acknowledgements. This work was supported in part by grant 3.120.77 from the Swiss National Science Foundation, and by contract NO1-AM-7-2213 from the National Health Institutes, Bethesda, Maryland. We are indebted to Drs. P. Gorden, A. Perrelet and S. Falkmer for critical reading of the manuscript. We thank M. Sidler-Ansermet, D. Mottier, I. Bernard, and P. A. Ruttiman for their valuable help in various aspects of this work.

\section{References}

1. Boucher D. W., Notkins, A. L.: Virus-induced diabetes mellitus. I. Hyperglycemia and hypoinsulinemia in mice infected with encephalomyocarditis virus. J. Exp. Med. 137, 1226-1239 (1973)

2. Boucher D. W., Hayashi K., Rosenthal J., Notkins A. L.: Virus-induced diabetes mellitus. MII. Influence of the sex and strain of the host. J. Infect. Dis. 131, 462-466 (1975)

3. Craighead, J. E., McLane, M. F.: Diabetes mellitus: induction in mice by encephalomyocarditis virus. Science 162, 913-914 (1968)

4. Craighead, J. E., Steinke, J.: Diabetes mellitus-like syndrome in mice infected with encephalomyocarditis virus. Am. J. Pathol. 63, 119-134 (1971)

5. Müntefering H.: Zur Pathologie des Diabetes mellitus der weißen Maus bei der EMC-Virusinfektion. Virchows Arch. [Pathol. Anat.] 356, 207-234 (1972)

6. Notkins, A. L.: Virus-induced diabetes mellitus. Arch. Virol. 54, 1-17 (1977)

7. Yoon J.-W., Notkins, A. L.: Virus induced diabetes mellitus. VI. Genetically determined host differences in the replication of encephalomyocarditis virus in pancreatic beta cells. J. Exp. Med. 143, 1170-1185 (1976)

8. Hayashi, K., Boucher, D.W., Notkins, A. L.: Virus induced diabetes mellitus. II. Relationship between beta cell damage and hyperglycemia in mice infected with encephalomyocarditis virus. Am. J. Pathol. 75, 91-102 (1974)

9. Orci, L., Baetens, D., Rufener, C., Amherdt, M., Ravazzola, M., Studer, P., Malaisse-Lagae, F., Unger, R. H.: Réactivité de la cellule à somatostatine de lin̂lot de Langerhans dans le diabète expérimental. C. R. Acad. Sci. [D] (Paris) 281, 1883-1885 (1975)

10. Orci, L., Baetens, D., Rufener, C., Amherdt, M., Ravazzola, M., Studer, P., Malaisse-Lagae, F., Unger, R. H.: Hypertrophy and hyperplasia of somatostatin containing D-cells in diabetes. Proc. Acad. Sci. (USA) 73, 1338-1342 (1976)

11. Patel, Y. C., Cameron, D. P., Bankier, A., Malaisse-Lagae, F., Ravazzola, M., Studer, P., Orci, L.: Changes in somatostatin concentration in pancreas and other tissues of streptozotocin diabetic rats. Endocrinology (in press)

12. McEvoy, R. C., Hegre, O. D.: Morphometric quantitation of the pancreatic insulin-, glucagon-, and somatostatin-positive cell populations in normal and alloxan-diabetic rats. Diabetes 26, 1140-1146 (1977)

13. Sundler, F., Håkanson, R., Lundquist, I., Larsson, L.-I.: Effect of alloxan on rat pancreatic polypeptide (PP) cells. Cell Tissue Res. 178, 307-312 (1977)

14. Baetens, D., Stefan, Y., Ravazzola, M., Malaisse-Lagae, F., Coleman, D. L., Orci, L.: Alteration of islet cell populations in spontaneously diabetic mice. Diabetes 27, 1-7 (1978)

15. Coons A. H., Leduc E. H., Connolly J. M.: Studies on antibody production. I. A method for the histochemical demonstration of specific antibody and its application to a study of the hyperimmune rabbit. J. Exp. Med. 102, 49-63 (1955)

16. Patel, Y. C., Cameron, D. P., Stefan, Y., Malaisse-Lagae, F., Orci, L.: Somatostatin: Widespread abnormality in tissues of spontaneously diabetic mice. Science 198, 930-931 (1977)

17. Weibel, E. R.: Stereological principles for morphometry in electron microscopy. Int. Rev. Cytol. 26, 235-302 (1969)

18. Weibel, E. R.: Stereological techniques for electron microscopic morphometry. In: Principles and techniques of electron microscopy. Biological applications, Vol. 3. Hayat, M. A. (ed.), p. 237-296. New York: Van Nostrand Reinhold Comp. 1973

19. Cahn, J. W., Nutting, J.: Transmission quantitative metallography. Trans. Am. Inst. Mining Mec. Engrs. 215, 526-528 (1959)

20. Wellmann, K. F., Amsterdam, D., Brancato, P., Volk, B. W.: Fine structure of pancreatic islets of mice infected with the $M$ variant of the encephalomyocarditis virus. Diabetologia $\mathbf{8}$, 349-357 (1972)

21. Wellmann, K. F., Amsterdam, D., Brooks, J. E., Volk, B. W.: Glucose tolerance and pancreatic ultrastructure in mice with long-term diabetes induced by EMC virus (M-variant) (38518). Proc. Soc. Exp. Biol. Med. 148, 261-262 (1975)

22. Zaheer, F., Howell, S. L., Taylor, K. W., Gamble, D. R.: Pancreatic insulin and glucagon content and secretion after infection of mice with EMC virus. Biochem. Soc. Trans. 5, 1058-1060 (1977)

23. Petersen, K. G., Heilmeyer, P., Kerp, L.: Synthesis of proinsulin and large glucagon immunoreactivity in isolated Langerhans islets from EMC-virus infected mice. Diabetologia 11, 21-25 (1975)

Received: April 10, 1978, and in revised form: June 28,1978

L. Orci

Institute of Histology and Embryology

Department of Morphology

University of Geneva Medical School

CH-1211 Geneva 4

Switzerland 